\title{
BEETHOVEN'S INSTRUMENTAL MUSIC
}

\author{
Translated from E. T. A. Hoffmann's Kroisleriana \\ with an introductory note
}

By ARTHUR WARE LOCKE.

\section{INTRODUCTORY NOTE}

E. T. A. HOFFMANN is an important figure in the background of musical history of whom we have gradually lost sight in spite of his significant relationship to the course of musical events and to those greater creative personalities by whom he was overshadowed. Hoffmann is known today chiefly for the part he took in the German literary movement of the first quarter of the nineteenth century. He also has a small place in the history of musical composition as the composer of the opera Undine, which had a successful run in Berlin in 1816. But his importance in the history of music does not come from the value of his numerous musical compositions which, curiously enough, coming from such a professedly radical romanticist in matters of music, follow the conservative methods of Spontini rather than the more progressive romantic style of Weber. Hoffmann did, however, exert a powerful influence on composers, critics, and the musical public through his literary writings in which he emphasized what at that time had little recognition in musical criticism, the romantic interpretation of music.

Ernst Theodor Wilhelm Hoffmann was born at Konigsberg in 1776, six years after Beethoven was born, and died in Berlin in 1822, five years before Beethoven's death. He changed the Wilhelm in his name to Amadeus as a testimony to his enthusiasm for the works of Mozart. Trained to be a lawyer but possessing unusual gifts for both music and drawing, his life was one long vacillation between the sober career of a Kammer-Gerichts-Rath and the bohemian existence of a romantic artist. During the last years of his life in Berlin this romantic dualism of his nature expressed itself in days spent over ledgers and police records which he kept with exemplary conscientiousness and nights spent in the most fantastic revelries at Luther and Wegener's Weinhaus. 
In 1803, Hoffmann was serving as a district attorney at Warsaw, which had been ceded to Prussia in 1795 . In a letter to a friend, he wrote, "-a gay world, full of magic visions, shimmers and flickers about me-it seems as if something great must soon come of it-some kind of an artistic creation must appear out of the chaos!- whether it will be a book-an operaa painting-quod diis placebit. . . " and in his diary he writes, "Was I born to be a painter or a musician? I must put the question to the president of the senate or the prime minister; they would know!" As a matter of fact, at this time in Warsaw Hoffmann seemed to be making a highly successful combined use of his varied talents. Besides satisfactorily and faithfully performing his official legal duties, he conducted orchestral concerts in a newly opened concert-hall which he had helped to plan and on the interior decoration of which he had demonstrated his skill as a painter. His friend Hitzig wrote of his success as a conductor:

His tempi were fiery and fast but without exaggeration, and people used to say afterward that if he had been able to show what he could do with a good orchestra, it would not have been easy to find a conductor to surpass him in the interpretation of Mozart. He had already at that time brought out a Beethoven symphony (Eroica?) for which he was filled with admiration.

Partly as a result of some caricatures which he had drawn of his superiors, Hoffmann lost his government position and took up music as a profession. It was in 1809 and 1810 while he was eking out a bare existence as musical director at the theatre at Bamberg that the first of his Kreisleriana papers appeared in the $A l_{g e m e i n e} M$-usitealische Zeitung at Leipzig. These with other fantastical musical essays were published in book form at Bamberg in 1814, and it is from this time that Hoffmann's literary career really dates. His fame as a teller of weird stories spread through numerous translations into other countries, particularly into France. Balzac, Theophile Gautier, Gerard de Nerval, and George Sand extolled him, and his praises were sung in verse by Alfred de Musset in Namouna in 1833. Carlyle helped to introduce him to English readers by translating Der goldne Topf. In some ways the weird fancifulness of his style may be compared to the style of Edgar Allan Poe, though W. C. Brownell in his American Prose Writers considers Hoffmann more human than Poe. Scott in an essay On the Supernatural in Fictitious Compositions' spoke 
of Hoffmann's stories as the feverish dreams of a diseased brain, comparing them to the visions which are produced by the immoderate use of opium and concluding that they were the result of the condition of Hoffmann's broken-down physique. But Scott lacked the sense for the weird and the supernatural which was such a characteristic element in the romantic imagination. Hoffmann's use of the supernatural was, like Coleridge's, the result of the exaltation of the imagination over the intellect and falls directly in line with his romantic interpretation of music as shown in the essay on Beethoven's Instrumental Music.

The full title of the two volumes published in Bamberg in 1814 is: Fantasiestitcke in Callot's ${ }^{1}$ Manier.' Blïtter aus dem Tagebuche oines reist len Enthusiasten. Mit einer Vorrede von Jean Paul. Among the contents is a ghost story about Gluck containing a description of the overture to Iphigenia in Aulis and a fantastic dream picture of a performance of Mozart's Don Juan. There are six essays under the general title Kroisleriana of which Beethoven's Instrumental Musik is No. 4. The name Kreisleriana comes from the weird figure of the Kapellmeister Johannes Kreisler around whom the subject matter centers. It is not known why Hoffmann chose the name Kreisler. The description of his character-a struggling musician at odds with the world, ranting against the philistinism of musical society and rhapsodizing about his art-is obviously autobiographical."

The essay on Beothooen's Instrumental Music is important as a contemporary criticism of Beethoven and as a demonstration of the growing tendency in music towards the romantic as opposed to the classic point-of-view. As an appreciation of the Fifth Symphony this essay is very remarkable when contrasted with the contemporary criticism which comidered the Third and Fifth Symphonies as a falling off from the First and the Second. Philip Spitta has said:

Hidden in the Rroisleriana there is a power of extraordinary force which has permeated all the writing about music during the century. The pictures of the three great Austrian instrumental composers which Hoffmann has drawn and placed next to one another are conceived with such deep-seeing musical insight and portrayed with such successful 1086).

1Jacques Callot, celebrated Prench etcher, engraver, and caricaturiat (1802-

'Sir George Grove in his Dictionnry in an article on Jacob Bbhner gives this man the credit of being the original from whom Hoffmann drew the portrait of Kreialer. Dr. Edgar Istel in the recent Reclam edition of the Rroisloriane does not mention Buhner. It is more likely that the character is drawn principally from Hofmann'. own experiences. 
poetic power that they are as effective to-day as when Hoffmann sketched them. ${ }^{2}$

Hoffmann's appreciation of the imaginative qualities in music made a strong appeal to those composers who were striving not so much to get away from classical forms as to make music more personal and more poetically suggestive. In 1820 , Beethoven sent Hoffmann his greeting in these words:

I am aware that you interest yourself in my work. Allow me to say that it pleases me very much coming from a man gifted with such exceptional talents as you: I wish you all that is beautiful and good.

Schumann in his youth immersed himself in the imaginative, eccentric world of Jean Paul and Hoffmann, who, indeed, got many of his ideas from Jean Paul. Just as the Papillons is a reflection of Schumann's enthusiasm for Jean Paul's novel Dio Flegeljahre, the Kreisleriana and the titles of some of Schumann's other pieces such as Nachtstilcke and Fantasiestiucke testify to his reading of Hoffmann's writings. The general character of Schumann's $K$ roisleriana suggests admirably the rhapsodic outpourings of the Kapellmeister Kreisler of Hoffmann's sketches.

Hoffmann was one of the earliest writers to influence Wagner. As early as 1827, Hoffmann's stories with their background of Dresden life fascinated Wagner, and they continued to attract him all through his life because they took him back to the time when he was a struggling artist among the familiar scenes of city life which Hoffmann described. As remarkable as was Wagner's appreciation of Beethoven's genius, Ernest Newman in his recent book on Wagner as $M$ an and Artist reluctantly admits that Wagner was stimulated in his worship of Beethoven by Hoffmann. It can be shown that Hoffmann also anticipated many other of Wagner's ideas on art.

The essay on Beethoven's Instrumental Music is a revision of an article by Hoffmann in the Allgemeine Musikalische Zeitung (xii. Jahrgang, No. 40, July 4, 1810) on the Beethoven Fifth Symphony and the Trios, Op. 70, which had been published the year before by Breitkopf and Hirtel. The essay as it now stands was first published in 1813 in the Zeitung für die elegante Welt in Leipzig and afterwards reprinted in the Fantaisiestiucke in Callot's Manier when the collected Kroisleriana and other essays were published together for the first time.

'Denteche Rundecheu, Deen 1892, Obor Robert Sehumanus Schrift. 